\title{
Complementary homeo protein gradients in developing limb buds
}

\author{
Guillermo Oliver, ${ }^{1}$ Neil Sidell, ${ }^{2}$ William Fiske,, Camilla Heinzmann, ${ }^{3}$ T. Mohandas, ${ }^{3}$ Robert S. \\ Sparkes, ${ }^{3}$ and Eddy M. De Robertis ${ }^{1}$ \\ Departments of ${ }^{1}$ Biological Chemistry, ${ }^{2}$ Pathology, and ${ }^{3}$ Medicine and Pediatrics, University of California, School of \\ Medicine, Los Angeles, California 90024-1737 USA
}

\begin{abstract}
A new human homeo box-containing gene designated Hox-5.2 was cloned and mapped to human chromosome 2. This homeo box is related in sequence to Abdominal-B, a Drosophila homeotic gene that specifies identity of posterior segments. An antibody probe was made using a human Hox-5.2 fusion protein and was found to stain posterior regions of mouse, chicken, and Xenopus embryos. Unexpectedly, when the distribution of Hox5.2 antigen was compared with that of XlHbox 1 antigen, a non-overlapping and mutually exclusive pattern was detected (e.g., in developing limb buds, intestine, and somites). Regions expressing Hox-5.2 do not express XlHbox 1 protein, and vice versa. Hox -5.2 antigen is detected strongly in developing fore- and hindlimb buds, where it forms a gradient of nuclear protein throughout most of the mesenchyme. This gradient is maximal in distal and posterior regions. Hox-5.2 expression is activated in Xenopus limb regeneration blastemas, as expected for any gene involved in pattern formation. As described previously, a gradient of XlHbox 1 protein can be detected in the forelimb. The latter gradient has the opposite polarity to that of Hox-5.2, i.e., maximal in anterior and proximal mesoderm. These two opposing gradients (and possibly others) could be involved in determining positional values in developing limb buds.
\end{abstract}

[Key Words: Vertebrate embryogenesis; human homeo boxes; chromosomal mapping; gradients; limb development; Hox-5.2]

Received January 16, 1989; revised version accepted March 2, 1989.

How is genetic information translated into the spatial patterns of tissues that determine, for example, the differences between an arm and a leg? In vertebrate development it has been argued that pattern is established by combinations of mechanisms such as positional information, developmental fields, and morphogenetic gradients (Weiss 1939; Huxley and De Beer 1934; Child 1941). It has been suggested that gradients of morphogens (presumably small molecules or growth factors) provide cells with positional values (Wolpert 1969). The type of cellular response depends on the differentiation program of the responding tissue (perhaps provided by particular combinations of nuclear transcription factors). The vertebrate embryo is subdivided into fields of cells that respond to positional information signals by forming specific organs. In salamander embryos, fields for the formation of the forelimb, hindlimb, balancer, eye, and ear have been reported (Weiss 1939; Child 1941). Homeo box genes are expressed in defined bands along the antero-posterior (A-P) axis of Drosophila embryos, and in vertebrates similar patterns of positionspecific expression have been reported (reviewed by Holland and Hogan 1988; Wright et al. 1989). It has been proposed that these regions of homeo box expression could provide a molecular explanation for the establishment of developmental fields in the vertebrate embryo (Oliver et al. 1988b).
The existence of a gradient in vertebrates with all the expected properties of a diffusible morphogen is suggested by the finding that retinoic acid is 2.5 times more concentrated in the posterior region than in the anterior region of the developing chicken limb bud (Thaller and Eichele 1987). A gradient of nuclear protein in forelimb mesenchyme has been described for the Xenopus laevis Homeo box 1 (XlHbox 1) gene. This gradient is maximal in the anterior and proximal portion of the forelimb buds in both Xenopus and mouse embryos, and is absent in the hindlimb buds (Oliver et al. 1988b). The forelimb arises from a region contained within the early field of XlHbox 1 expression, whereas the hindlimb does not (Oliver et al. 1988b). Expression of the homologous newt gene (NvHbox 1) also has been studied during limb regeneration (Savard et al. 1988). Another homeo box gene, expressed in interdigital regions, has been implicated in limb morphogenesis (Benoit et al. 1989; Hill et al. 1989). Limb bud development is an interesting model for the study of pattern formation because positional values can be changed by simple experimental manipulations, resulting in malformations such as duplications or deletions of digits (Bryant and Muneoka 1986). Gradients of other proteins have been reported in vertebrates, but their function in development is unclear (ConstantinePaton et al. 1986; Rosa et al. 1988).

In Drosophila embryos, protein gradients have been 
reported for the products of some development-controlling genes. Genes such as caudal (Macdonald and Struhl 1986; Mlodzik and Gehring 1987), bicoid (Driever and Nüsslein-Volhard 1988a,b), and dorsal (Steward et al. 1988) are expressed in gradients involved in establishing positional information in the embryo.

In this paper we report the isolation of two new human homeo box genes that belong to a gene cluster located in chromosome 2. One of these genes, called human Hox-5.2, has a homeo domain similar to that of the Drosophila Abdominal- $B$ gene. Abdominal- $B$ is expressed in posterior segments of the fly embryo. In vertebrates, several genes with this type of homeo domain have been reported (Boncinelli et al. 1988; Scott et al. 1989) and one of them has been shown to have a posterior domain of expression (Sharpe et al. 1987). An antibody against a human Hox-5.2 fusion protein was prepared and found to immunostain the posterior region of the vertebrate body. The antigen recognized by this antibody is expressed in a transient gradient in hindlimb buds of mouse, chicken, and frog embryos. This gradient is maximal over the distal and posterior part of hindlimb bud mesenchyme. In the forelimb bud a similar gradient is present, and is complementary to the previously reported distribution of XlHbox 1 protein (Oliver et al. 1988b). In other words, regions that express high levels of Hox-5.2 antigen are devoid of XlHbox 1 protein. This suggests that one gene may repress expression of the other, as is known to occur in interactions between certain Drosophila homeotic genes. Hox-5.2 antigen is activated during Xenopus limb regeneration, as would be expected for a gene involved in transmitting positional information. The data suggest that interaction of these two opposing gradients could be involved in determining positional values in developing limb buds.

\section{Results}

Two new human homeo box genes from the Hox-5 cluster

A 350-bp cDNA clone was isolated by screening a human neuroblastoma cDNA library at low stringency with a mixture of Xenopus homeo box probes. Its DNA sequence revealed a new human homeo box, which was then used as a probe for screening a human leukocyte genomic library at high stringency. The genomic clone isolated contained a homeo box corresponding to that of the cDNA used as probe, as well as a second homeo box located 5 ' to it (Fig. 1A). This defines two new genes that are transcribed in the LAN 5 human neuroblastoma cell line (in Northern blots two transcripts of about $2.6 \mathrm{~kb}$ and of $2.1 \mathrm{~kb}$ were detected for the first gene, and a single band of about $2 \mathrm{~kb}$ was found for the second one in this cell line, data not shown). The direction of transcription indicated in Figure 1 was deduced from DNA sequence analysis.

The mammalian genome contains several clusters of genes containing homeo boxes of the Antennapedia type (Fienberg et al. 1987; Boncinelli et al. 1988; Dressler and Gruss 1988) that presumably arose by large duplications

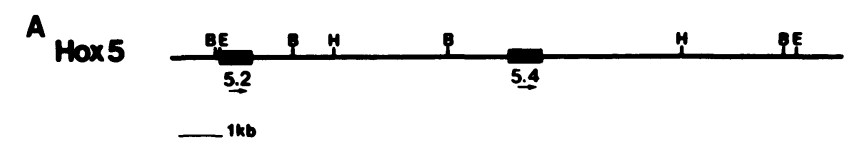

$\mathbf{B}$

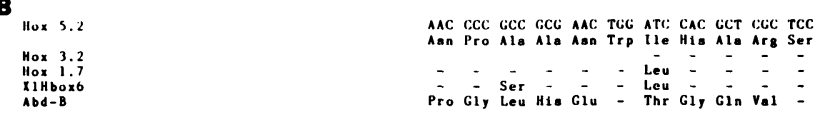

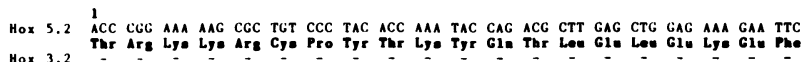

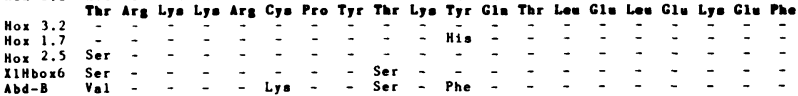

HOX 5.2 CTC TTC AAC ATG TAC CTC ACC CGC GAC CGG CGC TAC GAG GTG GCC AGG ATT CTC AAC CTA

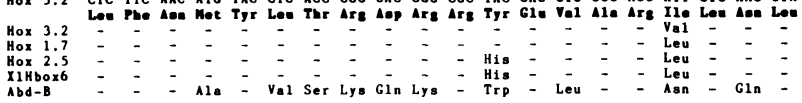
Hox 5.2 ACA GAG AGA CAG GTC AAA ATC TGG TTT CAG AAC CGT AGG ATG AAA ATG AAN AAG ATG AOC

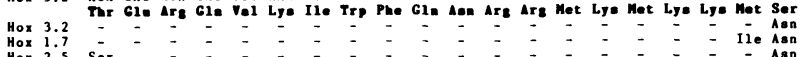

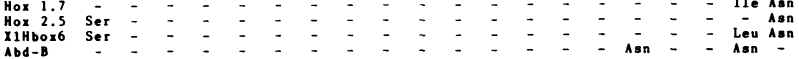

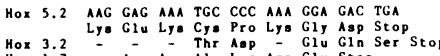

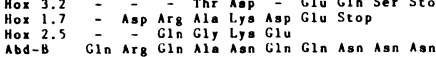

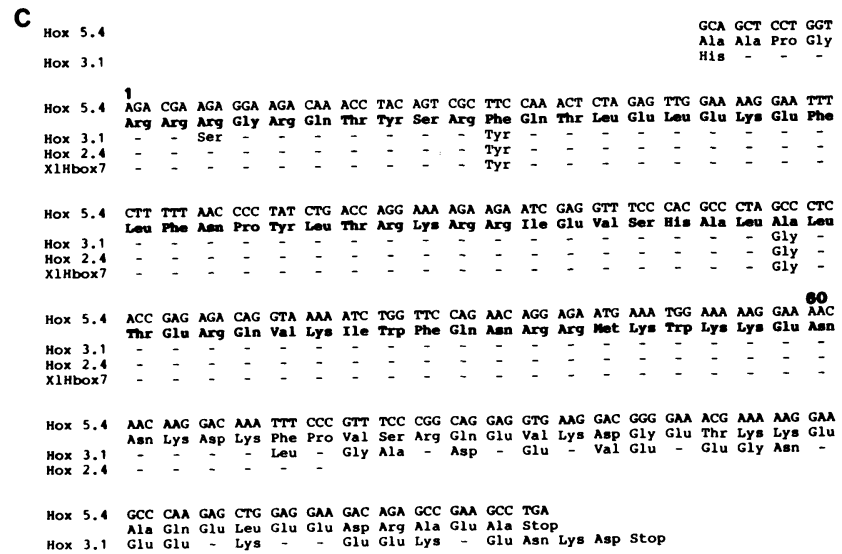

Figure 1. Genomic organization of the region of the human Hox-5 cluster containing Hox-5.2 and Hox-5.4 homeo boxes and evolutionary relationships with other homeo domain proteins. (A) Map of the genomic clone containing the new human homeo box-containing genes Hox-5.2 and Hox-5.4: $(E)$ EcoRI, $(B)$ BamHI, $(H)$ HindIII. Arrows indicate direction of transcription. $(B)$ Comparison of related homeo domain sequences of the subfamily comprising Hox-5.2 (human), Hox-3.2, Hox-1.7, Hox-2.5 (mouse), $X 1 H b o x 6$ (frog), and Abdominal-B (Drosophila). (C) Subfamily of vertebrate genes including the homeo domains of Hox-5.4 (human), Hox-3.1, Hox-2.4 (mouse), and XlHbox 7 (frog).

during evolution. Chromosome mapping is the simplest approach for determining to which cluster a new human homeo box gene belongs. Probes prepared from both homeo box genes were hybridized separately to a panel of 17 mouse-human somatic cell hybrids (Fig. 2A). The results unambiguously assigned both genes to human chromosome 2. By in situ hybridization to metaphase 

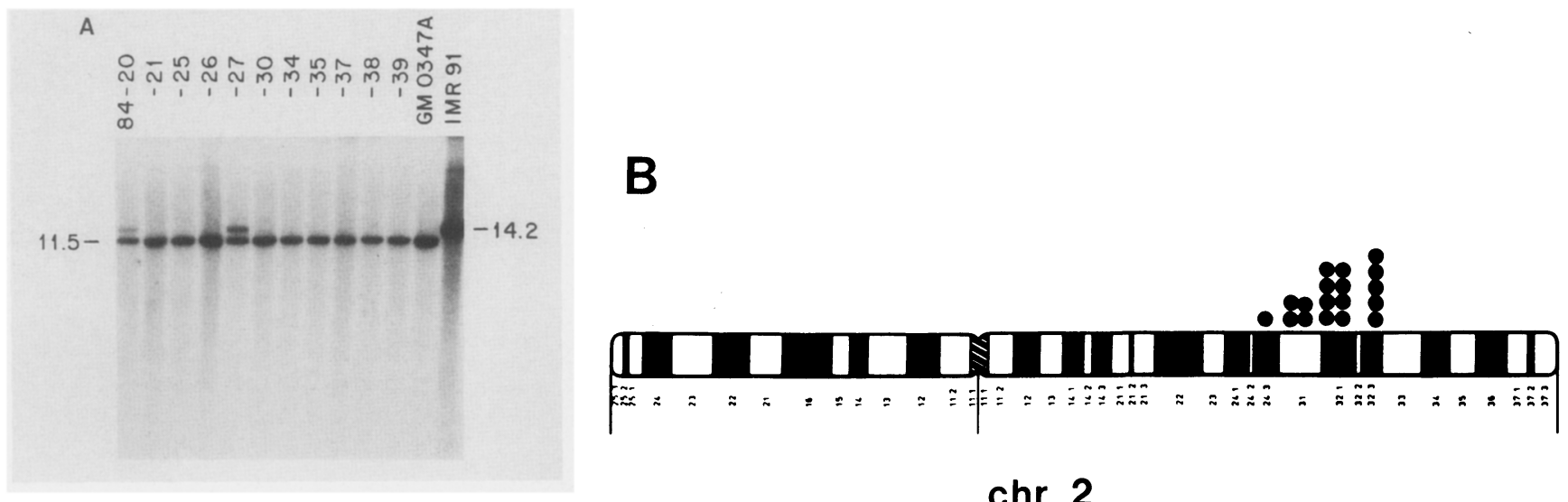

\section{$\operatorname{chr} 2$}

Figure 2. Segregation of human Hox -5 genes in somatic cell hybrids and chromosomal localization by in situ hybridization. (A) Southern analysis of human-mouse somatic cell hybrids using the human Hox-5.4 cDNA as a probe (for description of the cell lines, named at the top of the panel, see Mohandas et al. 1986). The lanes contain representative hybrids; GM 0347A is the mouse and IMR 91 is the human control. A $14.2-\mathrm{kb}$ band in the human cell line can be distinguished from an $11.5-\mathrm{kb}$ band in the mouse genome. The presence of the human band in two cell lines allows us unambiguously to assign Hox-5.4 to human chromosome 2 . The same analysis was carried out with a human Hox-5.2 probe. $(B)$ In situ hybridization distribution of silver grains on a diagramed G-banded human chromosome 2 . In this analysis the $1.8-\mathrm{kb}$ BamHI restriction fragment corresponding to human Hox-5.2 homeo box was used as probe. The main concentration of grains is over region $2 \mathrm{q} 31-2 \mathrm{q} 32$, with a peak at $2 \mathrm{q} 32.3$, indicating that this is the site of the Hox-5 locus. Similar results were obtained using a human Hox-5.4 probe.

chromosomes, it was determined that both genes map in the region 2q31-2q32 (Fig. 2B). A human homeo box gene, called $c 13$, had been mapped previously to this region (2q31-2q37; Mavilio et al. 1986; Cannizzaro et al. 1987), defining the human Hox-5 complex (Boncinelli et al. 1988). The murine homolog of $c 13$ also has been cloned and called Hox-5.1 (Featherstone et al. 1988). Recently, a murine homeo box gene named Hox-5.2 has been isolated and determined to be linked physically to the Hox-5.1 gene (D. Duboule, pers. comm.). Another mouse homeo box gene (Hox-5.3) was identified $6 \mathrm{~kb} \mathrm{5}$ to Hox-5.2 (D. Duboule, pers. comm.). On the basis of sequence similarities and following the recommended nomenclature (Martin et al. 1987), we consequently named our human genes Hox-5.2 and Hox-5.4 (Fig. 1A). The human Hox-5.2 is the homolog of mouse Hox-5.2. The murine homolog of the human Hox-5.4 has not yet been identified.

Homeo domains can be grouped into subfamilies according to their sequences (Boncinelli et al. 1988; Scott et al. 1989). Human Hox-5.2 belongs to a subfamily containing murine genes Hox-1.7, Hox-2.5, and Hox-3.2 as well as Xenopus XlHbox 6 (Fig. 1B). These genes are located towards the $5^{\prime}$ end of homeo box complexes and are most related in sequence to the Drosophila Abdominal- $B$ gene, which is the most posteriorly expressed gene of the bithorax complex. Human Hox-5.4 belongs to a subfamily containing murine homeo boxes 2.4 and 3.1, and Xenopus XlHbox 7 (Fig. 1C). This type of vertebrate homeo box is always located immediately $3^{\prime}$ to a member of the Abdominal- $B$ family (human Hox -5.4 is $3^{\prime}$ to Hox-5.2; Hox-2.4 is $3^{\prime}$ to 2.5 ; Hox-3.1 is $3^{\prime}$ to 3.2 ; and Xenopus XlHbox 7 to $3^{\prime}$ to XlHbox 6; Boncinelli et al. 1988; Breier et al. 1988; Fritz et al. 1989). In the mammalian genome, therefore, these two types of homeo box gene are present at least three times (in the Hox-2, Hox-3, and Hox-5 complexes).

\section{Hox-5.2 is expressed posteriorly}

Antibodies were generated against a fusion protein containing the last 73 amino acids, including the homeo domain, of human Hox-5.2. Antigens recognized by this antiserum were analyzed in paraffin sections of mouse embryos. To facilitate analysis, in every case we stained the adjacent section with anti-XlHbox 1 antibodies, whose staining pattern had been described in detail previously (Oliver et al. 1988a,b). Comparison of Figure 3, A (XlHbox 1) and B (Hox-5.2), shows that Hox-5.2 antigens are detected only in posterior regions of the embryonic spinal cord, somites, and mesoderm of the digestive tract. In contrast, $X l$ Hbox 1 is detected in more anterior regions of the body, which, in general, do not express Hox-5.2 antigen. Similar staining patterns were found with both antibodies in sections of frog and chicken embryos (data not shown), consistent with the finding that antibodies against homeo proteins-cross react between different vertebrate species (Oliver et al. 1988a). The apparent overlap in central nervous system staining seen in Figure 3, A and B, is due to staining of two different types of neuronal populations by each antibody (data not shown).

Because the human Hox-5.2 fusion protein was derived from a genomic DNA fragment containing the entire homeo box region, it was necessary to test the specificity of the antibody. When anti-human Hox-5.2 antiserum was depleted over affinity columns containing either XlHbox 1 or XlHbox 2 homeo domain proteins, so that all cross-reacting antibodies were removed (tested by Western blots of fusion proteins), the staining pattern 


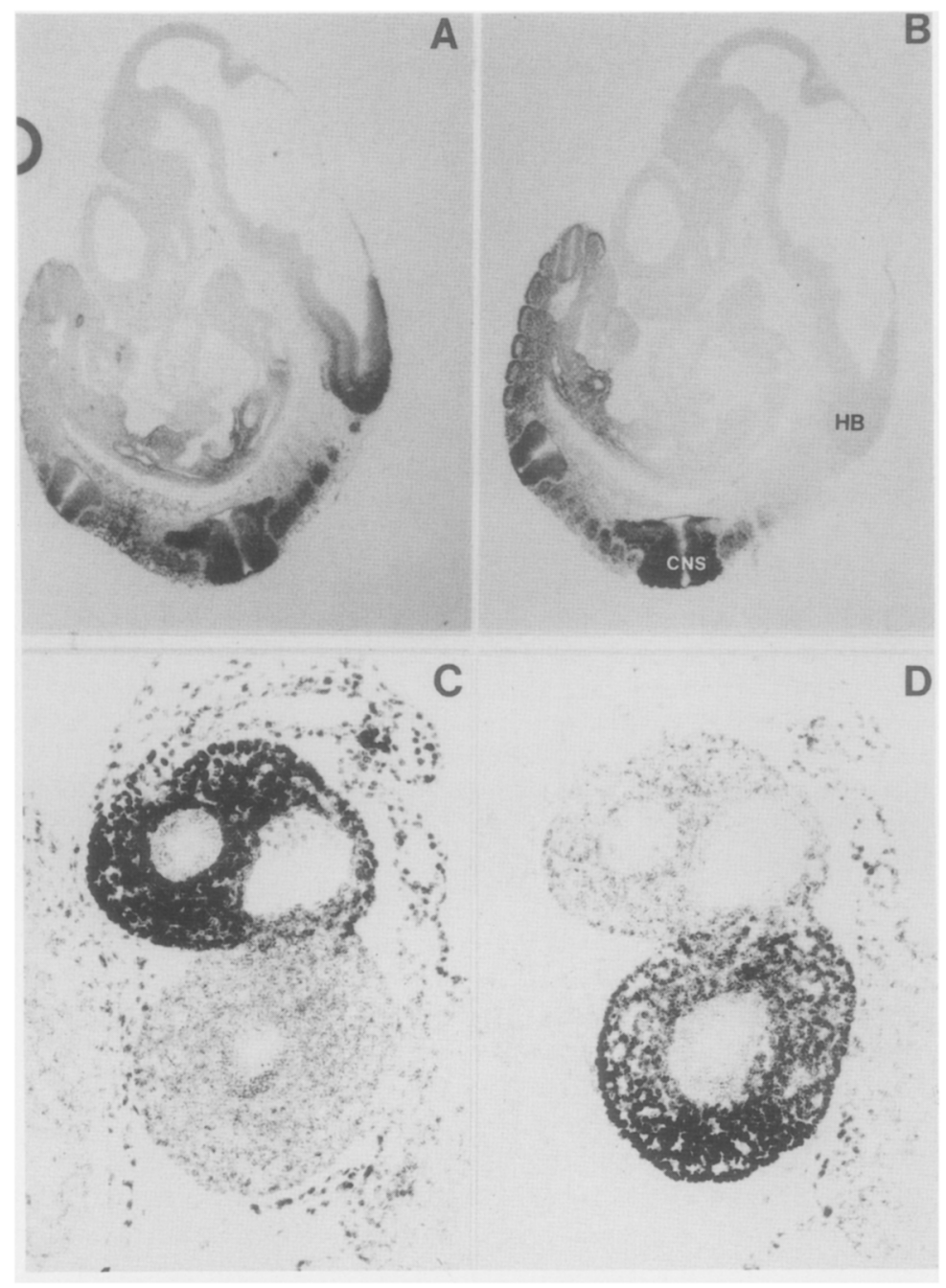

Figure 3. Hox-5.2 antigen in mouse embryos is expressed posteriorly and exhibits a pattern complementary to that of $X 1 H b o x$. $(A)$ Day-10.5 mouse embryo sectioned parasagittally and stained with an antibody raised against the last 106 amino acids of the human homolog of the XlHbox 1 gene (Oliver et al. 1988a). The protein is detected in anterior regions of the spinal cord beginning in the hindbrain (HB), in somites, and in mesoderm of the digestive tract. $(B)$ The adjacent mouse section was immunostained with antiHox -5.2 antibody (raised against the last 73 amino acids of the protein). Nuclear staining is detected over the same tissue derivatives as $X$ lHbox 1, but its distribution is in more posterior regions of the embryo (e.g., this protein is absent in hindbrain and only the posterior digestive tract is stained). The mutually exclusive expression pattern of both proteins is better seen in the two following panels. (CNS) Central nervous system. (C) Transverse section through an intestinal loop of a mouse embryo stained with XlHbox 1 antibody. Staining is detected in the mesoderm of an anterior intestinal loop. (D) Adjacent section immunostained with anti-Hox-5.2 antibody; note that only the posterior intestinal loop is positive. These mutually exclusive staining patterns strongly support the specificity of the antibodies used in this analysis.

on embryo sections was unaffected. Antibodies depleted in this way were used interchangeably with the undepleted antibody throughout the study. In addition, fusion proteins were added as competitors during the immunostaining reaction itself. As expected, Hox-5.2 protein abolished staining, while addition of either XlHbox 1 or XlHbox 2 proteins containing the entire homeo domain did not result in any change. The best argument in favor of Hox-5.2 antibody reacting in a very specific way is that it stains different body regions than other antibodies raised against fusion proteins containing other homeo domains of the Antennapedia type (Fig. 3). However, because there are other genes very related to human Hox-5.2 in the mammalian genome (Hox-1.7, Hox-2.5, Hox-3.2, Fig. 1B|, we cannot exclude the possibility that the antibody might cross-react with them. Consequently, the Hox-5.2 antigens to which we refer throughout this paper could include other genes of the Antennapedia- $B$ subfamily or very related, still undiscovered, genes. This antibody, however, has proved to be a very useful marker for studying limb development.

Hox-5.2 and XlHbox 1 are expressed in non-overlapping regions

Figure 3 shows that the Hox-5.2 and XlHbox 1 antigens 
are expressed in mutually exclusive regions of the mouse embryo. This is particularly striking if one compares Figure 3, C and D. The mesoderm of an anterior intestinal loop stains strongly with XlHbox 1 antibody, whereas that of a more posterior one does not (Fig. 3C). Conversely, Hox-5.2 antigen is expressed in the posterior intestinal loop, but not in the anterior one (Fig. 3D). This differential staining of the anterior and posterior digestive tract can also be observed in Figure 3, A and B.

Expression in non-overlapping domains of the body was also found in frog and chicken embryos. In the spinal cord both antibodies stain different subsets of neurons; a similar type of complementarity was also noted in mesonephric tubules (data not shown). The mutually exclusive nature of the expression of these two antigens was also manifested in developing limb buds (see below). This complementary expression is reminiscent of the behavior of certain Drosophila homeotic genes, in which expression of one gene represses that of another (Hafen et al. 1984).

\section{A homeo box protein expressed in developing hindlimbs}

In developing hindlimbs of a 10.5-day mouse, XlHbox 1 is expressed only in the ectoderm (Fig. 4A), whereas Hox-5.2 antigen is expressed in mesodermal cells (Fig. 4B). Expression is strongest in the distal part of the hindlimb bud, forming a gradient of nuclear protein. The Xenopus embryo displays similar staining patterns (Fig. $4 \mathrm{C}, \mathrm{D})$, including the hindlimb bud gradient of Hox -5.2

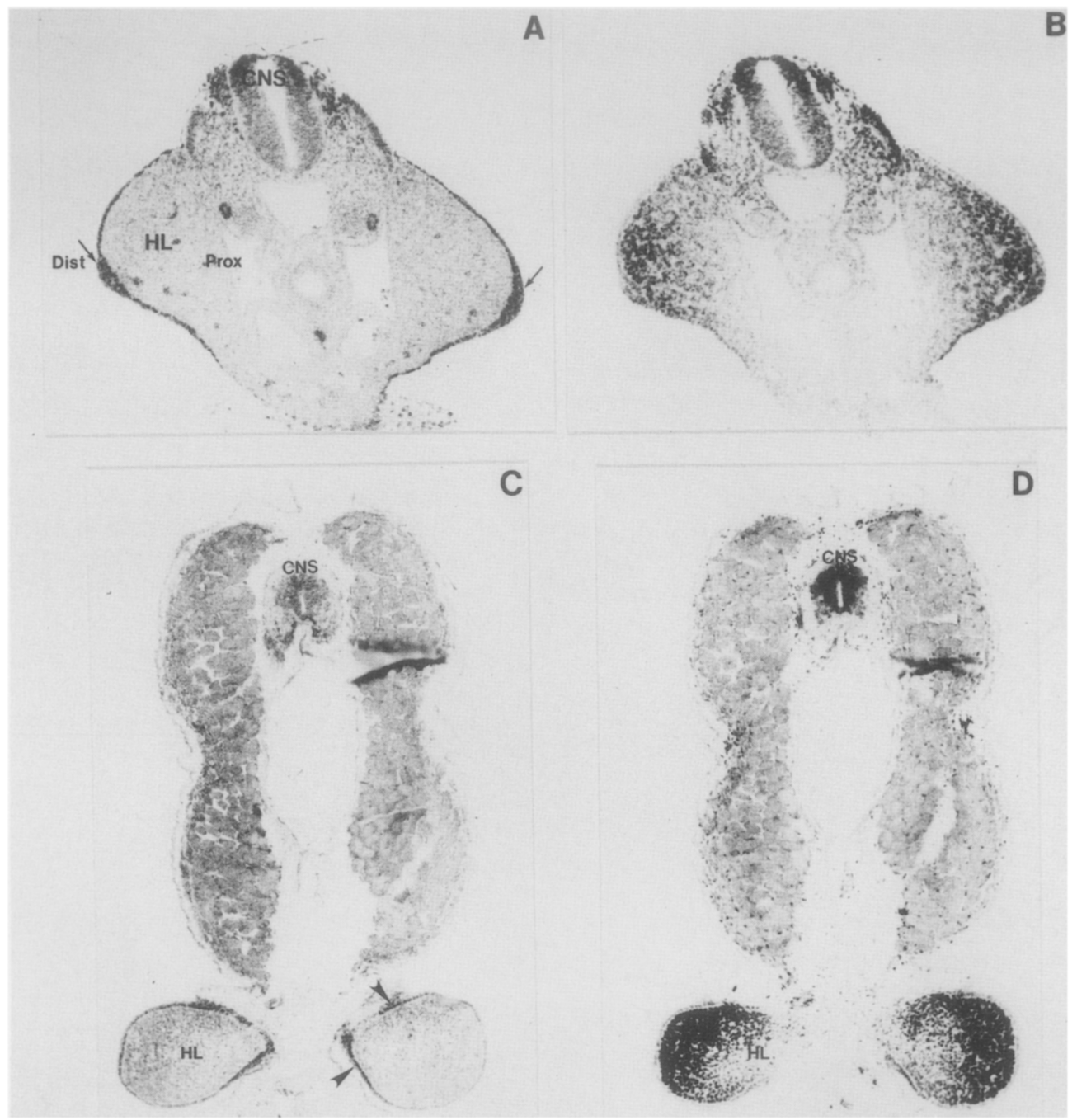

Figure 4. Immunolocalization of Hox-5.2 antigens in developing hindlimb buds. (A) Day-10.5 mouse embryo hindlimb buds (HL) sectioned transversely and stained with the XlHbox 1 antibody raised against the human homolog (Oliver et al. 1988b). As described previously, staining is detected only in the surrounding ectoderm (indicated by arrows). (B) Staining of an adjacent section with anti-Hox-5.2 antibody. Mesodermal cells exhibit a distal (Dist) to proximal (Prox) gradient of nuclear protein. (C) Transverse section at the level of the hindlimb buds of a Xenopus stage-50 tadpole (2-week) stained with Xenopus antibody B (Cho et al. 1988; Oliver et al. 1988a). As previously reported (Oliver et al. 1988b), no mesodermal staining is detected in hindlimbs, while the medial region of the ectoderm shows expression (arrows). (D) An adjacent section was stained with anti-Hox-5.2 antibody and, as in mouse, the staining is observed in the mesoderm in a distal to proximal gradient. (CNS) Central nervous system. 
antigen. The 'progress zone,' a distal region where most limb growth takes place (Tickle et al. 1975), strongly expresses Hox-5.2 antigen at early stages. Intense mesodermal staining is only present in early hindlimb buds, with antigen loss starting at the distal tip by day 12 in mouse embryos. As the limb develops, Hox-5.2 staining becomes weaker and is restricted to nuclei of cells that are differentiating into cartilage (day 13 in mouse, stage 53 in tadpoles, data not shown).

\section{Two opposing gradients in forelimb buds}

Hox-5.2 antigen was detected not only in hindlimb buds, but it also stained forelimb bud mesoderm intensely, as can be seen in Figure 5B. As reported previously (Oliver et al. 1988b), XlHbox 1 protein is expressed in the forelimb bud mesoderm as a gradient that is maximal in the anterior and proximal regions (Fig. 5A). Hox-5.2 antigen expression is complementary to that of XlHbox 1: It is strongly expressed in mesodermic regions negative for $X 1 H b o x$, and is absent from the ectoderm (Fig. 5B).

In the forelimb, Hox -5.2 antigen is also expressed in a gradient, as can be seen in the stage- 25 chicken wing bud shown in Figure 6 /which was sectioned in an oblique plane, so that the left side of the photograph is distal as well as more posterior, while the right side is proximal as well as more anterior). A distal-to-proximal gradient (highest at the tip of the limb) can be observed clearly. Serial sections of this and other chicken limbs reveal that the gradient is also posterior to anterior (higher in the posterior limb bud, i.e., the region that will bear the little finger). The same type of gradient was observed in forelimb buds of Xenopus and mouse embryos. As was the case in the hindlimb, the Hox-5.2 gradient in the forelimb is transient and starts disappearing from the distal end of the mouse forelimb bud by day 12 .

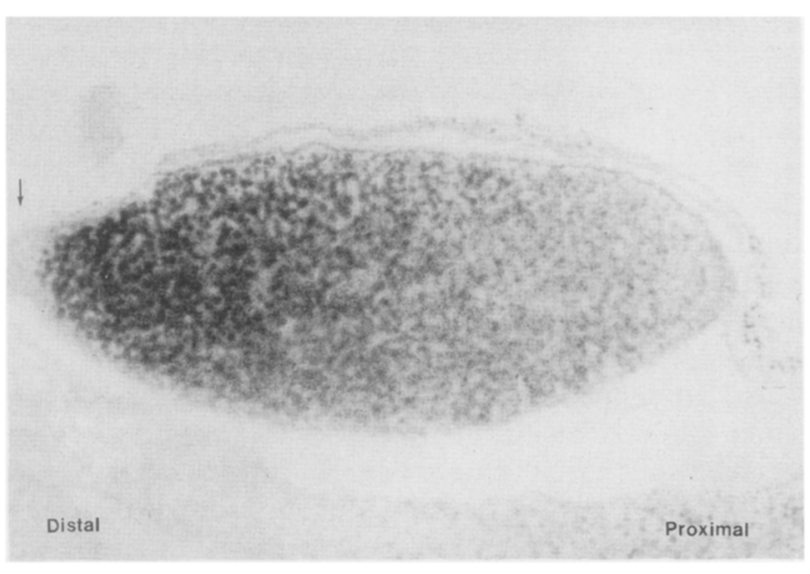

Figure 6. Section through a stage- 25 chicken forelimb showing a clear nuclear gradient of Hox-5.2 antigen. In this oblique section Hox-5.2 gradient is maximal in the distal (and posterior) region, and minimal in the proximal (and anterior) region of the limb bud. The arrow indicates the apical ectodermic ridge, a thickening of the ectoderm involved in limb growth.

We conclude that in the forelimb Hox-5.2 is expressed in a gradient with the opposite polarity to that of $X 1 H b o x$ 1. The Hox-5.2 gradient has an orientation similar to that of the proposed retinoic acid gradient (Thaller and Eichele 1987).

\section{Homeo protein induction in regenerating limb buds}

The mechanisms that control pattern formation during amphibian limb regeneration are similar to those operating during embryonic development (Bryant and Muneoka 1986). Following amputation of a limb, a regeneration blastema is formed from dedifferentiated stump

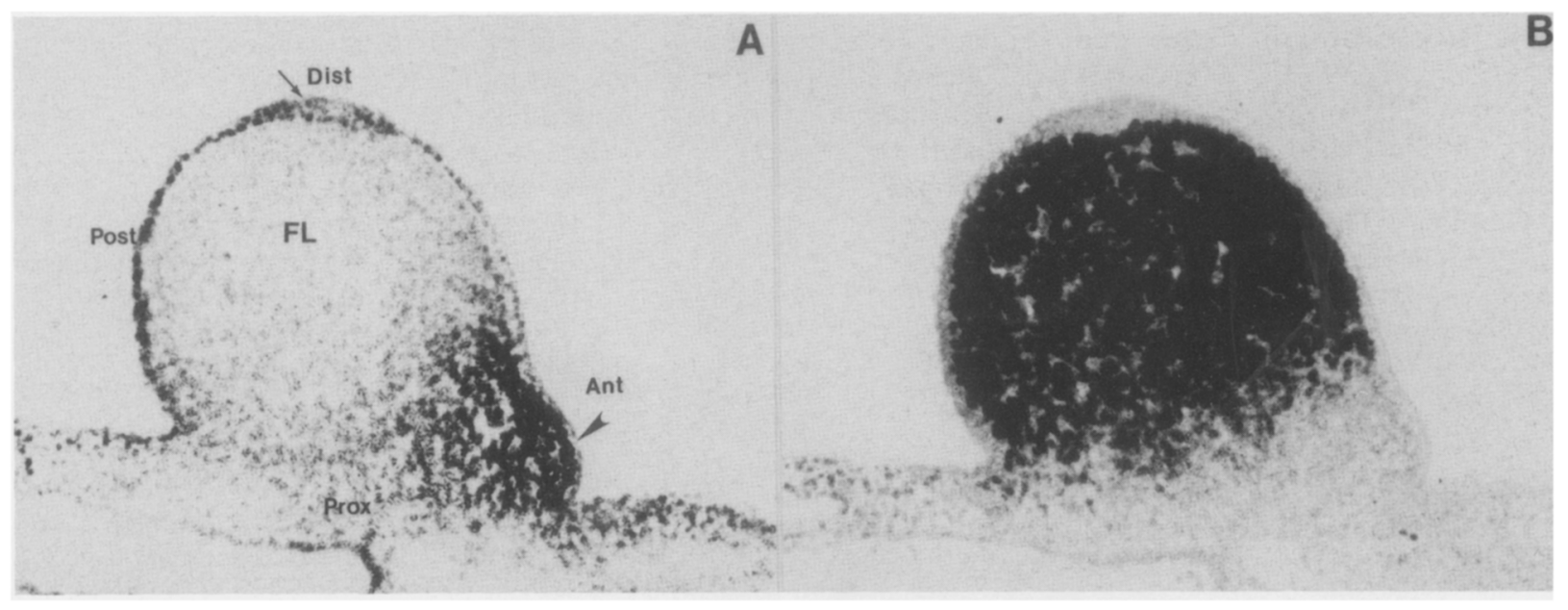

Figure 5. Anti-Hox-5.2 antibody staining in developing day-10.5 mouse forelimbs. $(A)$ Longitudinal (frontal) section at the level of the forelimb (FL) bud stained with the human XlHbox 1 antibody. Staining is detected in the anterior (Ant) mesoderm and in the surrounding ectoderm. (Post) Posterior; (Prox) proximal; (Dist) distal. (B) Staining of an adjacent section with anti-Hox-5.2 antibody detects this antigen in a complementary pattern to that of $X l H b o x$, i.e., negative in the ectoderm and position in those mesodermal cells that do not show staining for XlHbox 1. 
tissues; it eventually produces a replica of the lost part. Transplantation studies have shown that positional values in the blastema can be respecified experimentally. Therefore, any gene product involved in pattern formation should also be active during limb regeneration. We analyzed Hox-5.2 antigen expression in Xenopus hindlimbs amputated at stage 52 ( 3 weeks of larval development). In contrast to salamanders, which can regenerate limbs even as adults, Xenopus is only able to regenerate limbs during the larval period. In stage-52 tadpoles, almost complete regeneration can be obtained (Dent 1962). Figure 7 shows sections of the hindlimbs of a tadpole from which the distal half of one leg was amputated 8 days previously. While at this late stage only very weak anti-Hox-5.2 staining is detected on the nonamputated side (Fig. 7A), strong expression is detected in nuclei of the regeneration blastema (arrows in Fig. 7B), consistent with a possible role of this gene product in pattern specification.

\section{Discussion}

We report here the isolation of two new homeo box genes, designated human Hox-5.2 and Hox-5.4. An antibody reacting with $H o x-5.2$ antigen was prepared, and the protein was found to be distributed as a nuclear gradient in fore- and hindlimb buds in mouse, chicken, and frog embryos. The gradient reported here has a polarity opposite to that described previously for XlHbox 1 protein in developing forelimb mesoderm (Oliver et al. 1988b). The Hox-5.2 gradient encompasses most of the limb bud mesoderm and is maximal at the distal tip and the posterior border (Fig. 6). At the height of its expression Hox-5.2 antigen is very strongly stained, but the gradient is transient and starts decreasing in the mouse limb bud by day 12 .

The early embryonic mesoderm is subdivided into fields expressing different homeo box genes, which are transiently reactivated later when organogenesis occurs (reviewed by Wright et al. 1989). In the case of Hox-5.2, this reactivation occurs during intestinal and limb bud differentiation. This antigen is also activated during regeneration of amputated Xenopus limbs. The latter finding is consistent with a possible role of Hox-5.2 in the transmission of positional information in the regeneration blastema (Stocum and Fallon 1982; Bryant and Muneoka 1986).

Antibody probes against homeo domain proteins are particularly useful because they permit one to study the expression of homologous genes in a wide variety of vertebrate embryos. As described above, a number of competition studies showed that anti-Hox-5.2 antibodies are rather specific and do not cross-react with other homeo domains of the Antennapedia type. Since there are a number of related genes within the Abdominal- $B$ subfamily in the mammalian genome, we cannot exclude that our antibody might cross-react with some of them. In situ hybridization to transcripts on embryo sections will establish whether the protein patterns we describe here are due exclusively to Hox-5.2 expression. However, in situ hybridization across species boundaries is not feasible (because it would require reduced stringency) and these studies would be difficult in the homologous (human) system. The main conclusion of this paper, i.e., that opposing gradients of homeo domain proteins exist during limb bud development, is valid whether the antibody recognizes solely Hox-5.2 or not.

Lewis (1978) has suggested that the linear order of homeotic genes in the chromosome is associated with their regions of expression along the anterior-posterior axis of the Drosophila embryo. Genes at the $5^{\prime}$ end of a cluster are expressed in more posterior segments of the fly (e.g., Abdominal- $B$, which is the most 5' gene of the bithorax complex is also the one expressed most posteri-

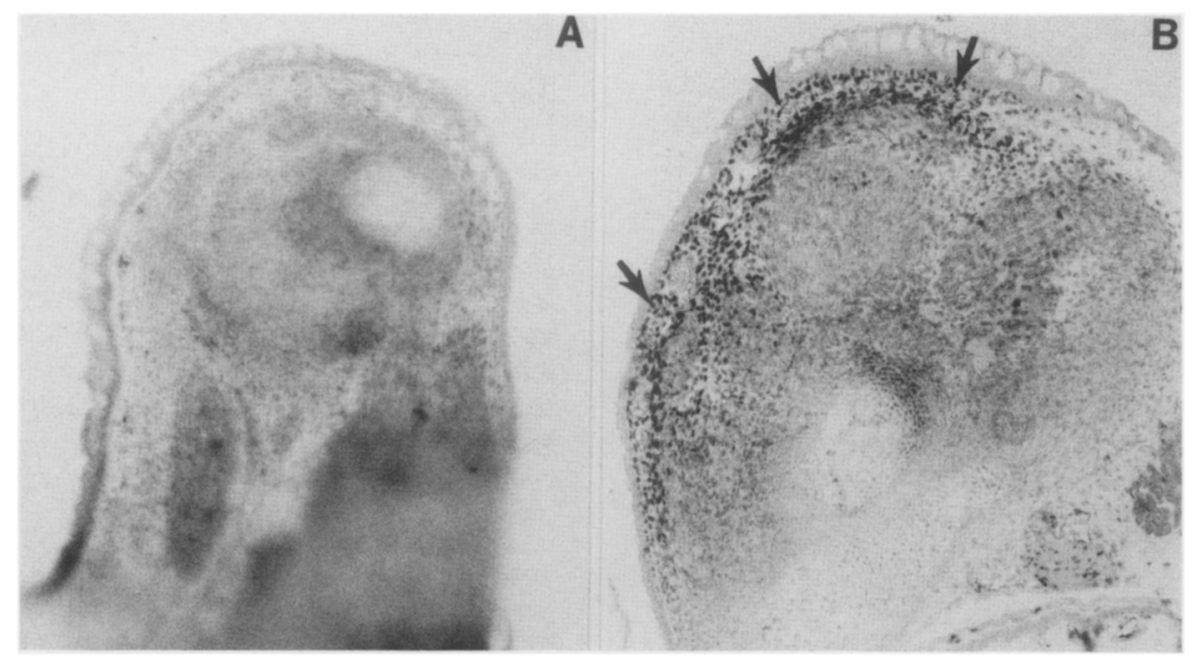

Figure 7. Activation of Hox-5.2 protein during limb regeneration. (A) Normal hindlimb bud from a stage-54 Xenopus tadpole (oblique section). Very weak staining is detected with Hox-5.2 antibody. (B) Contralateral hindlimb bud amputated distally 8 days previously (stage 52). Note that Hox-5.2 antigen is strongly expressed in the regeneration blastema (arrows). 
orly). It has been suggested that a similar correlation between position in a cluster and regions of expression may also exist in vertebrates (Boncinelli et al. 1988; Gaunt et al. 1988; Graham et al. 1988). Hox-5.2 antigens were found to be expressed in posterior regions of the embryonic mesoderm and central nervous system (Fig. $3 \mathrm{~B})$, as expected for a gene belonging to the Abdominal$B$ subfamily. Members of this subfamily in general are located in $5^{\prime}$ positions within vertebrate homeo box clusters (Boncinelli et al. 1988; Wright et al. 1989).

During the course of this study it was found unexpectedly that expression of a second homeo domain protein, XlHbox 1, is excluded from areas strongly positive for Hox-5.2. This results in embryos expressing the two antigens in non-overlapping subsets of cells. This is particularly obvious in Figure 3 , in which the mesoderm of an anterior intestinal loop expresses $X 1 H b o x 1$ while a posterior loop reacts with anti-Hox-5.2 antibodies, and also is valid for other embryonic regions such as the limb bud (Fig. 5). In Drosophila, homeotic genes are expressed in complementary and mutually exclusive regions of the embryo (Akam 1987). These patterns are thought to arise from interactions between homeotic genes in which expression of one gene represses that of the other (Lewis 1978; Hafen et al. 1984). If a similar mechanism exists in vertebrates, one might predict that microinjection of synthetic Hox-5.2 mRNA could, for example, repress transcription from $X 1 H b o x 1$ promoters.

The idea that gradients may provide a mechanism for specifying position in the embryo has been favored for many years, (Weiss 1939; Huxley and De Beer 1934; Child 1941; Wolpert 1969|. In the limb bud, interactions of the two opposing protein gradients described here (and possibly others) could be involved in determining positional values. An interesting question is how does a gradient of nuclear protein arise in a seemingly homogeneous population of mesenchymal cells. Presumably intercellular signaling mechanisms involving multiple gene products exist. A large number of mutations affecting limb development are known in both the chick (Abbot 1983) and mouse (Green 1981). Some of these mutations may affect such signaling mechanisms.

\section{Methods}

Isolation and characterization of the Hox-5 cluster

A human cDNA clone corresponding to Hox-5.4 was isolated by screening a human neuroblastoma cDNA library (purchased from Clontech) with homeo box probes isolated from genes $X 1 H b o x 1$ and X1Hbox 4 of X. laevis (Fritz and De Robertis 1988). A genomic clone carrying human Hox-5.2 and human Hox-5.4 genes was isolated by screening an EMBL3 human leukocyte genomic library (purchased from Clontech) with the human Hox-5.4 cDNA clone. Restriction fragments containing both homeo boxes were then subcloned into BlueScribe (Stratagene) and their DNA sequences were determined by doublestranded sequencing (Zagursky et al. 1985).

\section{Chromosome mapping and in situ hybridization}

A panel of 17 human-mouse somatic cell hybrids was derived from the fusion of normal human male fibroblasts (IMR 91) and thymidine kinase-deficient mouse cells (B82, GM 0347A), as described previously (Mohandas et al. 1986). Cytogenetic analysis was carried out on a minimum of $30 \mathrm{Q}$-banded metaphases per hybrid clone.

DNA from the parental and the somatic cell hybrid clones was purified from nuclei (Fodor and Doty 1979), digested with HindIII, and subjected to Southern blot analysis at high stringency as described by Sparkes et al. (1987), using as probe either the 350-bp insert of the human Hox-5.4 cDNA clone or a $1.8-\mathrm{kb}$ BamHI fragment of human Hox-5.2 which carries the homeo box (Fig. 1A).

The in situ hybridization analysis of normal human chromosomes was performed as described (Harper and Saunders 1981; Cannizzaro and Emanuel 1984) using the same two DNA probes. Slides were exposed for 1 week and silver grains located on the chromosomes or touching them were scored.

\section{Construction of $\beta$-galactosidase fusion protein and antibody preparation}

The 1.8-kb BamHI DNA fragment (shown in Fig. 1A) containing the human Hox-5.2 homeo box was fused in-frame to the carboxyl terminal of $\beta$-galactosidase in the vector $p T R B 2$ (Burglin and De Robertis 1987). This construct contains the first 5 amino acids upstream from the homeo box, the homeo box, and 8 amino acids downstream from the homeo box (Fig. 1A).

Fusion proteins were induced and isolated as described previously (Oliver et al. 1988a). A 6-week-old female New Zealand White rabbit was immunized with affinity-purified fusion protein. Each boost contained $2 \mathrm{mg}$ of protein. Rabbits were bled $(50 \mathrm{ml})$ via the marginal ear vein 10 days after each inoculation following the second boost. Antisera purification was as described (Oliver et al. 1988a). The two XlHbox 1 antibodies used in this study have been described previously and were antibody $B$ (used in all Xenopus sections) and a second antibody raised against the human XlHbox 1 homolog (Oliver et al. 1988a). The latter antibody gives stronger signals in mouse and chicken embryos.

\section{Immunostaining}

Xenopus laevis tadpoles were staged according to Nieuwkoop and Faber (1967). Pregnant BALB/c mice were purchased from Simmonsen Labs Inc. (California) and their embryos were staged according to Rugh (1968). The day of the vaginal plug was designated as day 0.5 post coitum. Chicken embryos were kindly provided by Dr. James Paulson and staged according to Hamburger and Hamilton (1951).

Embryos were fixed in Bouin's solution (75 parts saturated picric acid, 25 parts formaldehyde, and 5 parts glacial acetic acid), embedded in paraffin, and sectioned by microtome. $(8$ $\mu \mathrm{m})$. Sections were dewaxed by passage through xylene and graded ethanol baths ( 2 min each). Immunostaining was carried out as described previously (Oliver et al. 1988a,b) using as second antibody anti-rabbit IgG conjugated with alkaline phosphatase (Promega Biotec).

\section{Acknowledgments}

We would like to thank Drs. Larry Zipursky, Susan Bryant, Stanley Sessions, Louis Wolpert, Bruce Blumberg, and Dennis Bittner for critical reading of the manuscript; Ivana Klisak for expert technical assistance with the in situ chromosome mapping studies; Denis Duboule for sharing unpublished results; and Christopher Wright for his help in antibody preparation. 
This work was supported by the National Institutes of Health (grant HD 21502-04) and by the Norman Sprague Jr. Endowment for Molecular Oncology.

\section{Note added in proof}

The murine Hox-5.2 gene has been isolated recently by Dolle and Duboule (EMBO J., 1989, in press). When its transcript distribution was analyzed by in situ hybridization, the results were in complete agreement with the antibody data shown in this paper. This suggests that our antiserum is indeed directed mainly against the Hox-5.2 antigen.

\section{References}

Abbot, U.K. 1983. Genetic modification of limb morphogenesis. In Limb development and regeneration, Part A, (eds. J.F. Fallon and A.I. Caplan), pp. 13-31. (Alan R. Liss, New York).

Akam, M.E. 1987. The molecular basis for metameric pattern in the Drosophila embryo. Development 101: 1-22.

Benoit, R., D. Sassoon, B. Jacq, W. Gehring, and M. Buckingham. 1989. Hox-7, a mouse homeo box gene with a novel pattern of expression during embryogenesis. EMBO $J$. 8: $91-100$.

Boncinelli, E., R. Somma, D. Acampora, M. Pannese, M.D'Esposito, and A. Simone. 1988. Organization of human homeo box genes. Human Reprod. 13: 880-886.

Breier, G., G.R. Dressler, and P. Gruss. 1988. Primary structure and developmental expression of Hox-3.1, a member of the murine Hox-3 homeo box gene cluster. EMBO J. 7: 13291336.

Bryant, S.V. and K. Muneoka. 1986. Views of limb development and regeneration. Trends Genet. 2: 153-159.

Burglin, T.R. and E.M. De Robertis. 1987. The nuclear migration signal of Xenopus laevis nucleoplasmin. EMBO $J$. 6: $2617-2625$.

Cannizzaro, L.A. and B.S. Emanuel. 1984. An improved method for G-banding chromosomes after in situ hybridization. $\mathrm{Cy}$ togenet. Cell Genet. 38: 308-309.

Cannizzaro, L.A., C.M. Croce, C.A. Griffin, A. Simeone, E. Boncinelli, and K. Huebner. 1987. Human homeo box-containing genes located at chromosome regions $2 \mathrm{q} 31-2 \mathrm{q} 37$ and 12q12-12q13. Am. J. Hum. Genet. 41: 1-15.

Child, C.M. 1941. Patterns and problems of development, (University of Chicago Press, Chicago) pp. 272-303.

Cho, K.W.Y., J. Goetz, C.V.E. Wright, A. Fritz, J. Hardwicke, and E.M. De Robertis. 1988. Differential utilization of the same reading frame in a Xenopus homeo box gene encodes two related proteins sharing the same DNA-binding specificity. $E M B O J$. 7: 2139-2149.

Constantine-Paton, M., A.S. Blum, R. Mendez-Otero, and C.J. Barnstable. 1986. A cell surface molecule distributed in a dorsoventral gradient in the perinatal rat retina. Nature 324: 459-462.

Dent, J.N. 1962. Limb regeneration in larvae and metamorphosing individuals of the South African clawed toad. $J$. Morph. 110: 61-77.

Dressler, G.R. and P. Gruss. 1988. Do multigene families regulate vertebrate development? Trends Genet. 4: 214-219.

Driever, W. and C. Nüsslein-Volhard. 1988a. A gradient of bicoid protein in Drosophila embryos. Cell 54: 83-93.

- 1988b. The bicoid protein determines position in the Drosophila embryo in a concentration dependent manner. Cell 54: 95-104.

Featherstone, M.S., A. Baron, S.J. Gaunt, M. Mattei, and D. Du- boule. 1988. Hox5.1 defines a homeo-gene locus on mouse chromosome 2. Proc. Natl. Acad. Sci. 85: 4760-4764.

Fienberg, A.A., M.F. Utset, L.D. Bogarad, C.P. Hart, A. Awgulewitsch, A. Ferguson-Smith, A. Fainsod, M. Rabin, and R.H. Ruddle. 1987. Homeo box genes in murine development. Curr. Top. Dev. Biol. 23: 233-256.

Fodor, E.J.B. and P. Doty. 1979. Highly specific transcription of globin sequences in isolated reticulocyte nuclei. Biochem. Biophys. Res. Commun. 77: 1478-1485.

Fritz, A. and E.M. De Robertis. 1988. Xenopus homeo box-containing cDNAs expressed in early development. Nucleic Acids Res. 16: 1453-1469.

Fritz, A., K.W.Y. Cho, C.V.E. Wright, B. Jegalian, and E.M. De Robertis. 1989. Duplicated homeo box genes in Xenopus. Dev. Biol. 131: 584-588.

Gaunt, S.J., P.T. Sharpe, and D. Duboule. 1988. Spatially restricted domains of homeo-gene transcripts in mouse embryos: relation to a segmented body plan. Development 104: $169-179$.

Graham, A., N. Papalopulu, J. Lorimer, J.J. McVey, E.G.G. Tuddenham, and R. Krumlauf. 1988. Characterization of a murine homeo box gene, Hox-2.6, related to the Drosophila Deformed gene. Genes Dev. 2: 1424-1438.

Green, M.C. 1981. Genetic variants and strains of the laboratory mouse. Gustav Fischer Verlag, Stuggart.

Hafen, E., M. Levine, and W.J. Gehring. 1984. Regulation of Antennapedia transcript distribution by the bithorax complex in Drosophila. Nature 307: 287-289.

Hamburger, V. and H.L. Hamilton. 1951. A series of normal stages in the development of the chick embryo. J. Morphol. 88: 49-92.

Harper, M.E. and G.F. Saunders. 1981. Localization of single copy DNA sequence on G-banded human chromosomes by in situ hybridization. Chromosoma 83: 431-439.

Hill, R.E., P.F. Jones, A.R. Rees, C.M. Sime, M.J. Justice, N.G. Copeland, N.A. Jenkins, E. Graham, and D.R. Davison. 1989. A new family of mouse homeo box-containing genes: Molecular structure, chromosomal location, and developmental expression of Hox-7.1. Genes Dev. 3: 26-37.

Holland, P.W.H. and B.L.M. Hogan. 1988. Expression of homeo box genes during mouse development: A review. Genes Dev 2: 773-782.

Huxley, J.S. and G.R. De Beer. 1934. The elements of experimental embryology. Cambridge University Press, Cambridge.

Lewis, E.B. 1978. A gene complex controlling segmentation in Drosophila. Nature 276: 565-570.

Macdonald, P.M. and G. Struhl. 1986. A molecular gradient in early Drosophila embryos and its role in specifying the body pattern. Nature 324: 537-545.

Martin, G.R., E. Boncinelli, D. Duboule, P. Gruss, I. Jackson, R. Krumlauf, P. Lonai, W. McGinnis, F. Ruddle, and D. Wolgemuth. 1987. Nomenclature for homeo box-containing genes. Nature 325: 21-22.

Mavilio, F., A. Simeone, A. Giampaolo, A. Faiella, V. Zappavigna, D. Acampora, G. Poiana, G. Russo, C. Peschle, and E. Boncinelli. 1986. Differential and stage-related expression in embryonic tissues of a new human homeo box gene. Nature 324: 664-667.

Mlodzik, M. and W.J. Gehring. 1987. Hierarchy of the genetic interactions that specify the anteroposterior segmentation pattern of the Drosophila embryo as monitored by caudal protein expression. Development 101: 421-435.

Mohandas, T., C. Heinzmann, R.S. Sparkes, J. Wasmuth, P. Edwards, and A.J. Lusis. 1986. Assignment of human 3-hydroxy-3-methyglutaryl coenzyme A reductase gene to 
Oliver et al.

q13-q23 region of chromosome 5. Somat. Cell Mol. Genet. 12: 89-94.

Nieuwkoop, P.D. and J. Faber. 1967. Normal table of Xenopus laevis. (North Holland Publishing Co., Amsterdam).

Oliver, G., C.V.E. Wright, J. Hardwicke, and E.M. De Robertis. 1988a. Differential antero-posterior expression of two proteins encoded by a homeo box gene in Xenopus and mouse embryos. EMBO I. 7: 3199-3209.

Oliver, G., C.V.E. Wright, J. Hardwicke, and E.M. De Robertis. 1988 b. A gradient of homeo domain protein in developing forelimbs of Xenopus and mouse embryos. Cell 55: 10171024.

Rosa, F., T.D. Sargent, M.L. Rebbert, G.S. Michaels, M. Jamrich, H. Grunz, E. Jonas, J.A. Winkles, and I.B. Dawid. 1988. Accumulation and decay of DG42 gene products follow a gradient pattern during Xenopus embryogenesis. Dev. Biol. 129: 114-123.

Rugh, R. 1968. The mouse. Burgess Minneapolis.

Savard, P., P.B. Gates, and J.P. Brockes. 1988. Position dependent expression of a homeo box gene transcript in relation to amphibian limb regeneration. EMBO I. 7: 4275-4282.

Scott, M., J.W. Tamkun, and G.W. Hartzel III. 1989. The structure and function of the homeo domain. BBA Reviews on Cancer (in press)

Sharpe, C.R., A. Fritz, E.M. De Robertis, and J. Gurdon. 1987. A homeo box-containing marker of posterior neural differentiation shows the importance of predetermination in neural induction. Cell 50: 749-758.

Sparkes, R.S., T. Mohandas, C. Heinzmann, H.J. Roth, I. Klisak, I. and A.T. Campagnoni. 1987. Assignment of the myelin basic protein gene to human chromosome 18q22-q25. Hum. Genet. 75: 147-150.

Steward, R., S.B. Zusman, L.H. Huang, and P. Schedl. 1988. The dorsal protein is distributed in a gradient in early Drosophila embryos. Cell 55: 487-495.

Stocum, D.L. and J.F. Fallon. 1982. Control of pattern formation in urodele limb ontogeny: A review and a hypothesis. I. Embryol. Exp. Morphol. 69: 7-36.

Thaller, C., and G. Eichele. 1987. Identification and spatial distribution of retinoids in the developing chick limb bud. $\mathrm{Na}$ ture 327: 625-628.

Tickle, C., D. Summerbell, and L. Wolpert. 1975. Positional signalling and specification of digits in chick limb morphogenesis. Nature 254: 199-202.

Weiss, P. 1939. Principles of development (Holt, New York).

Wolpert, L. 1969. Positional information and the spatial pattern of cellular differentiation. J. Theor. Biol. 25: 1-47.

Wright, C.V.E., K.W.Y. Cho, G. Oliver, and E.M. De Robertis. 1989. Vertebrate homeo domain proteins: Families of region-specific transcription factors. Trends Biochem. Sci. (in press)

Zagursky, R., K. Baumeister, N. Lomax, and M. Berman. 1985. Rapid and easy sequencing of large linear double-stranded DNA and supercoiled plasmid DNA. Gene Anal. Techn. 2: 89-94. 


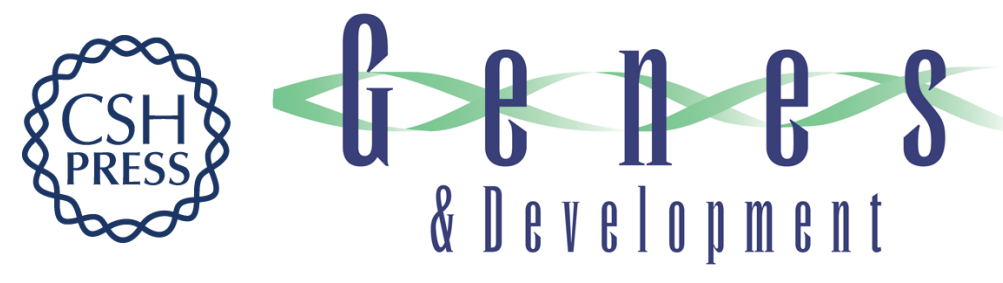

\section{Complementary homeo protein gradients in developing limb buds.}

G Oliver, N Sidell, W Fiske, et al.

Genes Dev. 1989, 3:

Access the most recent version at doi:10.1101/gad.3.5.641

References This article cites 44 articles, 7 of which can be accessed free at: http://genesdev.cshlp.org/content/3/5/641.full.html\#ref-list-1

License

Email Alerting Receive free email alerts when new articles cite this article - sign up in the box at the top Service right corner of the article or click here.

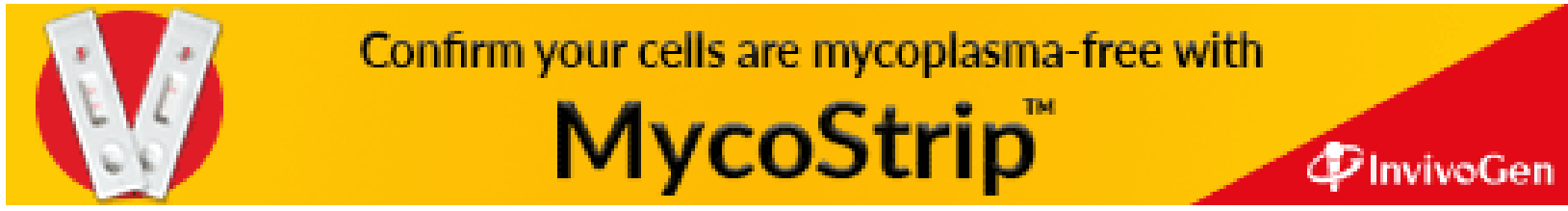

